\section{Commemoration of Prof. Haber's Death}

When Prof. Fritz Haber died in Switzerland a year ago, we were glad to publish in the columns of NATURE an eloquent tribute to his greatness, written by one of his old pupils. By the irony of political circumstances in Germany, the loss of this chemical genius was limited in the journals of that country to a bare announcement, and no obituary notice at all adequate to the influence of his life and work appears to have been published at the time. It is not surprising, therefore, that Haber's scientific friends desired to honour his memory on the anniversary of his death, and that a number of them assembled for this purpose in the Harnackhaus of the Kaiser Wilhelm Gesellschaft on January 29, in spite of the official dis. approval of the celebration to which we referred last week (p. 176). The Berlin correspondent of The Times reported that the speakers at the meeting laid emphasis on Haber's devotion to his country and his scientific services. Prof. Max Planck, who presided, recalled that Haber's synthetic nitrate process had saved Germany from military and economic collapse in the first months of the War. "We repay loyalty with loyalty," he said, and he laid particular emphasis on the last three words in his closing tribute to "this great scholar, upright man, and fighter for Germany." Prof. Otto Hahn, director of the Kaiser Wilhelm Institute for Chemistry, and other speakers also bore testimony to the debt owed by Germany to Haber for his outstanding contributions to pure and applied chemistry, and in doing so they expressed the feelings of their colleagues throughout the world. It will be remembered that Haber resigned his post at Dahlem in the spring of 1933 and afterwards accepted an invitation of laboratory hospitality at Cambridge, where he went in October of that year. He intended to reside there permanently but died at Basle, where he had gone for a short holiday, on January 29, 1934.

\section{British Industries Fair}

THE British Industries Fair, 1935, organised by the Department of Overseas Trade, is being held at Olympia and the White City, London, on February 18-March 1. This year the Engineering and Hardware Section is to be held at Castle Bromwich, Birmingham, not simultaneously with the London sections, as previously, but later, on May 20-May 31. The textile and furnishing exhibits will be shown at the White City and the general articles, other than engineering and hardware products, will be exhibited at Olympia. There are 1,550 exhibitors at Olympia and the White City, of which more than 750 are from London. There are again notable increases in the space taken and the number of exhibitors, compared with last year's figures. An indication of the remarkable growth of the Fair is given by the fact that the advance catalogue, which is issued in nine languages, runs to 684 pages, or about 152,000 words. The exhibits of products of scientific interest at the Fair again cover a wide range and reveal markedly the increasing use of scientific products, both materials and instruments, in the field of industry. The Committee responsible for the organisation of the united exhibit of scientific instruments is to be congratulated on the important display at Olympia of scientific, optical and photographic instruments. Microscope object-glasses of great refinement of construction; microscope projection apparatus; sound projection apparatus for cinemas, with suit-case sound sets for commercial and educational purposes ; various forms of planimeters; pocket cameras and aircraft cameras; distant-reading thermometers; geophysical apparatus for prospecting for gold, minerals and oil--.these are but a few examples, selected almost at random, of the products that are being shown in this united exhibit. It is worth notice that, until two years ago, practically all the various forms of planimeters used in Great Britain came from abroad; and similarly, the particular geophysical apparatus referred to above was practically a German monopoly. It is good to note the enterprise of British scientific instrument manufacturers in these new fields.

\section{Whales and Whaling}

THE International Convention for the Regulation of Whaling, which came into force last month, is a first and important step towards the permanerit preservation of whales and whaling. Since whales are killed almost entirely outside territorial waters, any effective measures having these ends in view must be taken by all great whaling countries in common; and one of the most important aspects of this Convention is that it inaugurates international treatment of the whaling industry. The Convention is concerned with the whalebone whales, on which all but a small part of modern whaling is based. It prohibits the capture of right whales, which have been reduced in numbers almost to disappearance, and requires a far more thorough utilisation of the carcases of other whalebone whales than was customary. A quite common practice was to produce oil from the blubber (from which oil is most easily obtained) alone. The Convention requires the utilisation of specified parts of the carcase, in which it follows the whaling regulations of the Falkland Islands Dependencies, and recent Norwegian law. This is economically sound, since it enables a given quantity of oil to be obtained from fewer whales. There is reason for supposing that the whales so saved may in a single season reach some thousands. Lastly, the Convention provides for the collection and collation of the statistics of both capture and manufacture, which should prove of the greatest value in the development of a full and satisfactory regulation of whaling. It makes no provision for the limitation of whaling, and as this will probably prove essential if the industry is to be maintained, it is a step only towards the solution of the main whaling problem; yet it is a valuable advance, in which it is greatly to be hoped the few whaling States not at present signatories will soon see their way to participate.

\section{The Hoover (Boulder) Dam}

THE completion, just announced, of the great conerete structure originally known as the Boulder 